\title{
Evaluation of Risk Factors Affecting Development of Retinopathy in Premature Infants
}

\author{
Filiz Gül' $\mathbb{D}^{\mathbb{D}}$, Ali Bülbül² \\ 'Department of Pediatrics, University of Health Sciences Gaziosmanpaşa Training and Research Hospital, ístanbul, Turkey \\ 2Department of Pediatrics, Unit of Neonatal, University of Health Sciences Şişli Hamidiye Etfal Training and Research Hospital, İstanbul, Turkey
}

Cite this article as: Gül F, Bülbül A. Evaluation of Risk Factors Affecting Development of Retinopathy in Premature Infants. JAREM 2018; 8(3): 171-6.

\begin{abstract}
Objective: We aimed to investigate the prevalence, risk factors, and prognosis of retinopathy of prematurity in premature infants.

Methods: Between January1, 2008 and December 31, 2012 we included 537 premature infants born at the 34 $4^{\text {th }}$ gestational week and previously treated at the Neonatal Intensive Care Unit of our hospital. Risk factors for the development of retinopathy of prematurity were retrospectively reviewed.

Results: Our study included 290 female and 247 male infants; 90 of these infants (16.7\%) were at different stages of retinopathy of prematurity. Of these, $55(61.1 \%)$ had stage 1, $24(26.7 \%)$ had stage 2, 9 (10\%) had stage 3, and1 (1.11\%) had stage 5 retinopathy of prematurity. Spontaneous regression was observed in 77 patients; laserphotocoagulation surgery was performed in 13 patients, and anti-VEGF therapy was given to 2 patients. One patient developed total retinal detachment. Birth weight, gestational weeks, Apgarscore (1 ${ }^{\text {st }}$ and $5^{\text {th }}$ minutes), oxygen treatment duration, surfactant treatment, ventilator treatment and duration, maximum $\mathrm{FIO}_{2}$, anemia, transfusion, sepsis, apnea, intraventricular hemorrhage, Bronchopulmonary Dysplasia (BPD) other diseases (NEC, phototherapy, and PDA), antenatal steroid treatment, hospitalisation duration were significantly higher in patients with premature retinopathy; however, no significant difference was seen in sex, race, and maternal preeclampsia in these patients.

Conclusion: We found a lower incidence of premature retinopathy in our study than in other studies in the literature. The majority of our patients with retinopathy of prematurity required early mechanical ventilation and oxygen supplementation. A good understanding of the risk factors for the development of premature retinopathy and risk factors in premature infants and early diagnosis and treatment are very important for the prevention of blindness.
\end{abstract}

Keywords: Retinopathy of prematurity, risk factors, premature infants

\section{INTRODUCTION}

Retinopathy of prematurity (ROP) is a disease caused by the fibrovascular proliferation of the immature retinal vessels of premature infants (1). ROP is one of the leading causes of preventable blindness in childhood (2).

Low birth weight infants are provided to survive with improvements in neonatal intensive care conditions, but this results in more infants with ROP (2). ROP is the second most common cause of blindness in newborns in the United States. In the United States, approximately 500 newborns lose their vision every year due to ROP, and 2300 of them have various visual problems $(3$, 4). It is estimated that $6 \%-18 \%$ of childhood blindness is related to ROP in developed countries (5). The World Health Organization, in its vision 2020 program, included ROP disease as a public health problem among the priority preventable diseases (6).
Retinopathy of prematurity (ROP) is usually seen in infants with low birth weight. It was first called as "retrolental fibroplasia" in 1942 when premature infants were diagnosed with fibroblastic mass behind the lens (7). In the etiology of ROP, there is local retinal ischemia in the acute phase and the resulting neovascularization; there is membrane formation in the chronic phase, and then, retinal detachment can be seen (8). The incidence of ROP increases inversely with small gestational age and low birth weight.

For screening ROP, the American Academy of Pediatrics, American Association of Pediatric Ophthalmology and Strabismus, and American Academy of Ophthalmology recommend ROP screening to all premature infants born $<1500 \mathrm{~g}$, $<30$ weeks of gestation, or unstable 1500-2000 g birth weight infants at risk of ROP (9). Screening for ROP is recommended on postconcep-

ORCID IDs of the authors: F.G. 0000-0001-5158-6660; A.B. 0000-0002-3510-3056. 
tional week 31 for babies with $<27$ weeks of gestation and on postconceptional week 4 for premature infants with $>27$ weeks of gestation (10).

The aim of the present study was to determine the effective risk factors in the etiology for ROP development and the incidence of $\mathrm{ROP}$ and to evaluate the prognosis with treatment modalities in premature infants in our neonatal intensive care unit.

\section{METHODS}

\section{Study group}

All infants who were treated at the neonatal intensive care unit of our hospital between January 1, 2008 and December 31, 2012, whose gestational period was $\leq 34$ weeks, and who were examined for retinopathy were included in our study. Infants who had lost their lives prior to the retinopathy examination, who were transferred to different hospitals for various reasons, or who were not followed up due to being on postconceptional week 52 were excluded from the study.

\section{Study Data}

The antenatal, natal, and postnatal features and demographic data of the infants were collected retrospectively from patient files in accordance with the Declaration of Helsinki. Respiratory therapy models and characteristics (oxygen uptake time, highest $\mathrm{FiO}_{2}$ value, mechanical ventilation models and durations, and surfactant application) applied to all infants, follow-up diagnoses of infants, frequency of blood transfusions due to patent ductus arteriosus (PDA), intraventricular hemorrhage (IVH), necrotizing enterocolitis (NEC), sepsis, bronchopulmonary dysplasia (BPD), and anemia were recorded.

Table 1. Distribution of general characteristics of all infants included in the study

\begin{tabular}{|l|c|}
\hline Demographic characteristics & $\mathrm{n}=537$ \\
\hline Birth weight, $\mathrm{g}^{\star}$ & $1704 \pm 509$ \\
\hline Gestational age, week* & $31.7 \pm 2.7$ \\
\hline Apgar score & \\
\hline $1 \mathrm{~min}$ & $6.04 \pm 1.41$ \\
\hline $5 \mathrm{~min}$ & $8.21 \pm 1.09$ \\
\hline Gender, $\mathrm{n}(\%)$ & \\
\hline Female & $290(54 \%)$ \\
\hline Male & $247(46 \%)$ \\
\hline Antenatal steroid administration, $\mathrm{n}(\%)$ & $159(29.6)$ \\
\hline ROP, $\mathrm{n}(\%)$ & $90(16.8)$ \\
\hline Multiple pregnancies, $\mathrm{n}(\%)$ & $58(12.1)$ \\
\hline Mortality, $\mathrm{n}(\%)$ & $42(7.8)$ \\
\hline *Values are expressed as mean \pm standard deviation & \\
\hline
\end{tabular}

\section{ROP Examination}

The first examinations of premature infants were performed in the newborn unit at 4-6 weeks after birth or on postconceptional weeks 31-33. Patients who were discharged before the first examination were checked at the ROP polyclinic of the ophthalmology clinic. All infants diagnosed with ROP were followed up until postconceptional week 52. Results were recorded according to the international ROP classification (11).

\section{Statistical Analysis}

To determine the risk factors for development of ROP independently using stratified sampling, a case-control cross-sectional control group with the same gestational age, the same mean birth weight, and the same number was established among the patients. In this way, it was aimed to determine the risk factors that may affect ROP development without the effects of gestational week and birth weight.

Data were analyzed by using the Statistical Package for the Social Sciences version 21.0 program (IBM Corp., Armonk, NY, USA). Data were expressed as mean \pm standard deviation, percentage (\%), and median (minimum-maximum). Kolmogorov-Smirnov test was used to determine the distribution of variables. Mann-Whitney $U$ test and independent sample t-test were used to analyze quantitative data. Fisher's exact test was used to analyze qualitative data when chi-square test/chi-square conditions could not be provided. A p value $<0.05$ was accepted as statistically significant.

\section{RESULTS}

A total of 636 infants with a gestational age of $\leq 34$ weeks were born in our hospital during the study period. Of the 636 patients, 36 who were referred to different hospitals for various reasons during the study, 42 who died prior to the examination of ROP, and 21 who were not followed up after discharge were excluded from the study. Overall, 537 infants were included in the study. The mean gestational age of the infants was $31.7 \pm 2.7$ weeks, and $54 \%(n=290)$ were girls. On ROP examination, retinopathy at various stages was detected in $90(16.7 \%)$ infants. Of the 90 infants, 56 (62.3\%) had stage I, 24 (26.6\%) had stage II, 9 (10\%) had stage III, and 1 (1.1\%) had stage $V$ disease. The prenatal and natal characteristics of the subjects are shown in Table 1. The distribution

Table 2. Distribution of infants with ROP according to the stages within the total patient distribution

\begin{tabular}{|l|c|c|}
\hline & $\begin{array}{c}\text { No. of patients } \\
\text { with ROP, } \mathbf{n}\end{array}$ & $\begin{array}{c}\text { Ratio to total } \\
\text { patient (n:537), \% }\end{array}$ \\
\hline Stage I & 56 & 10.4 \\
\hline Stage II & 24 & 4.5 \\
\hline Stage III & 9 & 1.7 \\
\hline Stages IV and V & 1 & 0.1 \\
\hline Total & 90 & 16.7 \\
\hline ROP: retinopathy of prematurity & &
\end{tabular}


of infants with ROP according to the stages in the total patient distribution is shown in Table 2.

The mean gestational age of the patients with ROP was $28.3 \pm 2.6$ (23-34) weeks, and mean birth weight was 1148 \pm 335 (570-2100) g. It was determined that as birth weight and gestational age increased, the incidence of ROP decreased significantly $(p=0.00)$. There were significant differences with regard to birth weight, gestational week, 1 and 5 min Apgar scores, and antenatal steroid administration rates among infants with and without ROP (Table 3). There was no significant difference between the groups with and without ROP with regard to oxygen therapy demand,

\section{Table 3. Comparison of prenatal, natal, and postnatal features and risk factors between the groups with and without ROP}

\begin{tabular}{|c|c|c|c|}
\hline Risk factors & $\begin{array}{c}\mathrm{ROP}(+) \\
\mathrm{n}=90\end{array}$ & $\begin{array}{l}\mathrm{ROP}(-) \\
\mathrm{n}=447\end{array}$ & $p$ \\
\hline Birth weight, $g$ & $1148 \pm 335$ & $1816 \pm 463$ & 0.00 \\
\hline Gestational age, week & $28.3 \pm 2.6$ & $32.3 \pm 2.1$ & 0.00 \\
\hline Gender, male, n (\%) & $39(43.3)$ & $208(46.5)$ & 0.57 \\
\hline \multicolumn{4}{|l|}{ Apgar score } \\
\hline $1 \mathrm{~min}$ & $5.12 \pm 1.5$ & $6.23 \pm 1.3$ & 0.00 \\
\hline $5 \mathrm{~min}$ & $7.40 \pm 1.1$ & $8.37 \pm 1.0$ & 0.00 \\
\hline $\begin{array}{l}\text { Antenatal steroid treatment } \\
\text { rates, } n(\%)\end{array}$ & $46(51.1 \%)$ & $113(25.3 \%)$ & 0.00 \\
\hline $\begin{array}{l}\text { Preeclampsia in } \\
\text { mother, } \mathrm{n}(\%)\end{array}$ & $22(24.4)$ & $72(16.1)$ & 0.058 \\
\hline $\mathrm{O}_{2}$ therapy demand, $\mathrm{n}(\%)$ & $90(100)$ & $436(97.5)$ & 0.22 \\
\hline $\mathrm{O}_{2}$ therapy duration, day & $35.3 \pm 56.3$ & $5.9 \pm 9.2$ & 0.00 \\
\hline Maximum $\mathrm{FiO}_{2}$ value & $55.7 \pm 13.9$ & $40.5 \pm 12.6$ & 0.00 \\
\hline $\begin{array}{l}\text { Mechanical ventilator therapy } \\
\text { demand, } \mathrm{n}(\%)\end{array}$ & $85(94.4)$ & $276(61.7)$ & 0.00 \\
\hline $\begin{array}{l}\text { Mechanical ventilator } \\
\text { duration, day }\end{array}$ & $19.9 \pm 49.2$ & $3.1 \pm 5.4$ & 0.00 \\
\hline $\begin{array}{l}\text { Surfactant therapy demand, } \\
\mathrm{n}(\%)\end{array}$ & $63(70)$ & $113(25.3)$ & 0.00 \\
\hline $\begin{array}{l}\text { Erythrocyte transfusion } \\
\text { demand, } n(\%)\end{array}$ & $71(78.9)$ & $98(21.9)$ & 0.00 \\
\hline Anemia diagnosis, n (\%) & $79(87.8)$ & $163(36.5)$ & 0.00 \\
\hline Proven sepsis diagnosis, n (\%) & $33(36.7)$ & $68(15.2)$ & 0.00 \\
\hline IVH (stages III and IV), n (\%) & $40(44.4)$ & $51(11.4)$ & 0.00 \\
\hline BPD, n (\%) & $37(41.1)$ & $17(3.8)$ & 0.00 \\
\hline PDA, n (\%) & $12(13.3)$ & $14(3.1)$ & 0.08 \\
\hline Phototherapy treatment, $n(\%)$ & $74(82.2)$ & $294(65.7)$ & 0.00 \\
\hline NEC, n (\%) & $18(20)$ & $46(10.3)$ & 0.00 \\
\hline
\end{tabular}

which was one of the risk factors included in the study $(p=0.22)$. However, duration of oxygen treatment, maximum $\mathrm{FiO}_{2}$, requirement and duration of ventilator treatment, requirement of surfactant treatment, erythrocyte transfusion requirement, sepsis, apnea, IVH, BPD, NEC, phototherapy requirement, antenatal steroid administration, and hospital stay were significantly higher in patients with ROP (Table 3). It was observed that the presence of preeclampsia in mothers and gender did not make a significant difference in patients with ROP. In our study, $78.9 \%$ of patients with ROP were transfused $(26.7 \%$ before the examination, $16.7 \%$ after the examination, and $35.6 \%$ before and after the examination). The rate of transfusion was significantly higher in patients with ROP than in those without ROP (Table 3).

Among our cases, a case-control group consisting of 90 premature infants with the same mean gestational week and birth weight was determined using stratified sample. Thus, it was

Table 4. Comparison of perinatal and clinical risk factors in patients with ROP and with the control group constituted with stratified sampling

\begin{tabular}{|c|c|c|c|}
\hline Demographic characteristics & $\begin{array}{c}\mathrm{ROP}(+) \\
\mathrm{n}=90\end{array}$ & $\begin{array}{c}\text { Control } \\
\text { group } \\
n=90\end{array}$ & $p$ \\
\hline Gender, male, n (\%) & 39 (43.3) & 47 (52.2) & 0.23 \\
\hline Birth weight, $g$ & $1148 \pm 335$ & $1225 \pm 219$ & 0.07 \\
\hline Gestational age, week & $28.3 \pm 2.6$ & $28.9 \pm 1.4$ & 0.07 \\
\hline \multicolumn{4}{|l|}{ Apgar score } \\
\hline $1 \mathrm{~min}$ & $5.12 \pm 1.5$ & $5.59 \pm 1.3$ & 0.05 \\
\hline $5 \mathrm{~min}$ & $7.40 \pm 1.1$ & $7.80 \pm 1.1$ & 0.01 \\
\hline \multicolumn{4}{|l|}{ Risk factors } \\
\hline Preeclampsia in mother, $\mathrm{n}(\%)$ & $22(24.4)$ & $23(25.6)$ & 0.86 \\
\hline $\mathrm{O}_{2}$ therapy rate, $\mathrm{n}(\%)$ & $90(100)$ & $88(97.8)$ & 0.49 \\
\hline $\mathrm{O}_{2}$ therapy duration, day & $35.3 \pm 56.3$ & $14.2 \pm 15.4$ & 0.00 \\
\hline Maximum $\mathrm{FiO}_{2}$ & $55.7 \pm 13.9$ & $49.8 \pm 13.3$ & 0.06 \\
\hline $\begin{array}{l}\text { Mechanical ventilator therapy } \\
\text { rate, } \mathrm{n}(\%)\end{array}$ & $85(94.4)$ & $80(88.9)$ & 0.17 \\
\hline $\begin{array}{l}\text { Mechanical ventilator } \\
\text { duration, day }\end{array}$ & $19.9 \pm 49.2$ & $8 \pm 8.9$ & 0.00 \\
\hline $\begin{array}{l}\text { Erythrocyte transfusion } \\
\text { demand, } n(\%)\end{array}$ & $71(78.9)$ & $58(64.4)$ & 0.03 \\
\hline $\begin{array}{l}\text { Anemia diagnosis frequency, } \\
n(\%)\end{array}$ & $79(87.8)$ & $72(80)$ & 0.15 \\
\hline Clinical sepsis diagnosis, $\mathrm{n}(\%)$ & $33(36.7)$ & $27(30)$ & 0.26 \\
\hline IVH (stages III and IV), n (\%) & $40(44.4)$ & $25(27.8)$ & 0.02 \\
\hline BPD, n (\%) & $37(41.1)$ & $14(15.6)$ & 0.00 \\
\hline Hospitalization duration, day & $70.7 \pm 51.4$ & $48 \pm 21.9$ & 0.00 \\
\hline
\end{tabular}


aimed to determine the risk factors that may affect ROP development without the effect of the main risk factors, gestational week, and birth weight. The results of the comparison of the demographic characteristics of mothers and infants between the two groups are presented in Table 3. When the factors affecting ROP development were compared between the two groups, there was a significant difference with regard to the duration of oxygen therapy, duration of mechanical ventilation, presence of transfusion, and presence of IVH. In the group with ROP, 5 min Apgar score, antenatal steroid administration, duration of oxygen treatment, maximum $\mathrm{FiO}_{2}$, duration of ventilator therapy, IVH, BPD, and hospital stay were significantly higher (Table 4).

In the follow-up of infants with ROP, in 77 of the 90 infants, ROP findings completely regressed without needing any intervention, 13 underwent laser photocoagulation, two received anti-vascular endothelial growth factor (bevacizumab) additionally, and one had visual loss due to total retinal detachment.

\section{DISCUSSION}

Retinopathy of prematurity (ROP) is one of the leading causes of preventable blindness in childhood worldwide (11). Nowadays, with the development of neonatology and current approaches, extremely low birth weight premature infants' survival rates increased, but this resulted in an increase in morbidities that may be observed in the long term, such as ROP.

Many risk factors for formation of ROP have been studied since the beginning of the 1940s. It was found that the most important risk factors in ROP development are low birth weight and gestational age of the infant (12). Other identified risk factors include oxygen toxicity, low Apgar score, mechanical ventilation support, blood transfusion, acidosis, apnea, IVH, NEC, PDA, sepsis, and multiple pregnancies (11).

Different results have been reported with regard to the frequency of ROP. It has been reported in the literature that the incidence of ROP is approximately 16\%-65.8\% (13-15). In our country, the frequency of ROP in different studies varies between centers, and it is reported to be seen in $15.4 \%-36.3 \%(7,16-20)$. In the CRYO-ROP study of 4099 premature infants from 23 centers, the prevalence of ROP in infants born $<1251 \mathrm{~g}$ was $65.8 \%$ and $81.6 \%$ in infants $<1000 \mathrm{~g}(10)$. In the study conducted in our country between 1992 and 2005 with 465 premature infants, the total prevalence of ROP was found to be $30.3 \%$; when evaluated according to gestational week, it was reported to be $70 \%$ at $\leq 28$ weeks, $32 \%$ at $29-32$ weeks, and $15.5 \%$ at $\geq 32$ weeks (19). In a multicenter TR-ROP study of 6115 infants, the incidence of ROP was found to be $27 \%$, and the incidence of severe ROP ( $\geq$ stage III) was found to be $6.7 \%$ (21). In our study, the frequency of ROP in all stages was determined as $16.7 \%$, and this value was found to be in the lower limit of the reported values. This was thought to be due to two reasons: protocols applied in our hospital, especially in the use of oxygen and non-invasive ventilation strategies in infants with mechanical ventilation, and the mean birth weight and gestational age in our study were higher than the reported studies.
Although many risk factors have been defined for ROP, the most important risk factors have been shown to be gestational week and low birth weight $(22,23)$. In our study, the mean birth weight of patients with ROP was found to be significantly lower than those without ROP. Our results support this information. Palmer et al. (13), in their study of 4099 infants with birth weight $\leq 1250$ $\mathrm{g}$, reported that while the rate of ROP in infants $<750 \mathrm{~g}$ is $90 \%$, it decreases to $10 \%$ in infants $>1500 \mathrm{~g}$. However, there are significant differences in the distribution of ROP incidence according to gestational weeks. In our study, mean gestational week was found to be significantly lower in patients with ROP.

Several studies have been conducted to determine the effect of oxygen therapy on ROP, and high oxygen therapy has been reported to increase the frequency and severity of ROP in most of them. In our study, in accordance with the general findings in the literature, the duration of oxygen therapy in infants with ROP was found to be significantly longer than those without ROP. Yalaz et al. (24) reported a significant relationship between ROP development and prolonged oxygen treatment time. Patz reported ROP development in infants who received low level of oxygen $\left(\mathrm{FiO}_{2}=40 \%\right)$ to be $6 \%$ and high level of oxygen $\left(\mathrm{FiO}_{2}=65 \%-70 \%\right)$ to be $60 \%$ (25). In our study, it was found that the maximum $\mathrm{FiO}_{2}$ level in the ROP group was significantly higher than that in the group without ROP. An important cause of ROP development in infants weighing $>1500 \mathrm{~g}$ or with higher gestational weeks may be uncontrolled oxygen therapy administered in the incubator. When oxygen saturation as measured by pulse oximetry is $>85 \%$ $90 \%$ due to fetal hemoglobin elevation in premature infants, the oxygen concentration in the blood is not known very precisely. Therefore, it is stated in the literature that maintaining oxygen saturation in premature infants $<90 \%$ may be protective for ROP (26).

Patent ductus arteriosus (PDA) relationship with ROP has been studied in many studies. Chen et al. (27) found that there is a two-fold higher risk for ROP in patients with PDA and band ligation, whereas Wani et al. (28) found that PDA does not constitute a statistically significant risk in the development of ROP. In our study, more PDA was detected in the ROP group.

Necrotizing enterocolitis (NEC) is a disease caused by immaturity similar to ROP. Many studies have investigated whether there is a significant relationship between ROP and NEC. In our study, we found that the rates of NEC in patients with ROP were higher than those without ROP. Wani et al. (28) found the frequency of NEC to be a statistically significant risk factor for ROP, whereas Chen et al. (27) stated no significant relationship between ROP and NEC.

It is known that the frequency of blood transfusion demand in premature infants is related to ROP development (18-20). Since oxygen bonding of erythrocytes in adults is lower than those in premature infants, there is an increase in the amount of oxygen offered to the tissues by transfusion, resulting in inappropriate hyperoxia in the tissues and contributing to the development of ROP. Our study also supports the knowledge that transfusion poses a risk for ROP development, as reported in the TR-ROP study (21). 
Another risk factor that may affect the incidence of ROP in premature newborn is sepsis, which is a multisystem disease. It has been thought that it may cause the release of proinflammatory cytokines, may cause damage to the newly developing vessels in the retina, and may cause severe ROP through angiogenic agents. Chen et al. (27) had shown that sepsis increases the frequency of ROP by 4.5-fold in preterm infants with $>27$ gestational weeks. Wani et al. (28) reported that both bacterial and fungal sepses increase the risk of ROP. In our country, Yalaz et al. (24) and Kavurt et al. (18) found in their studies that sepsis increases ROP frequency. In our study, we found that the rates of proven sepsis in blood culture were significantly higher in patients with ROP.

\section{CONCLUSION}

We found that the frequency of ROP development was lower in our study than in reported studies. When the main risk factors in ROP development, gestational week, and birth weight were excluded, NEC, IVH, BPD, proven sepsis, blood transfusion frequency, and oxygen and mechanical ventilation duration were determined to be important risk factors in ROP development. All interventions to reduce risk factors that are effective in ROP development will reduce the frequency of ROP development. Knowing the risk factors for ROP development well and the early diagnosis and treatment of all premature infants with risk factors will decrease the incidence of vision loss that is an important morbidity.

Data were collected retrospectively using the file research information form in accordance with the Declaration of Helsinki. Therefore, informed consent was not obtained.

Ethics Committee Approval: Authors declared that the research was conducted according to the principles of the World Medical Association Declaration of Helsinki "Ethical Principles for Medical Research Involving Human Subjects", (amended in October 2013).

Informed Consent: Informed consent was not taken from patients due to the retrospective nature of the study.

Peer-review: Externallypeer-reviewed.

Author Contributions: Concept - F.G., A.B.; Design - F.G., A.B.; Supervision - F.G., A.B.; Resources - F.G.; Materials - F.G.; Data Collection and/ or Processing - F.G.; Analysis and/or Interpretation - F.G., A.B.; Literature Search - F.G.; Writing Manuscript - F.G.; Critical Review - A.B.

Conflict of Interest: The authors have no conflict of interest to declare.

Financial Disclosure: The authors declared that this study has received no financial support.

\section{REFERENCES}

1. Ergenekon E, Turan Ö, Özden Ş, Hirfanoğlu I, Bozkaya D, Önal E, et al. Türkiye'de prematüre retinopatisi sıklığının durumu. Çocuk Sağlığı ve Hastalıkları Dergisi 2010; 53: 4-9.

2. Babayiğit A, Bülbül A, Türkoğlu-Ünal E, Uslu S, Güran Ö, Zübarioğlu $U$, et al. Prematüre retinopatisi gelişim sıklığı ve etki eden risk faktörlerinin değerlendirilmesi. Bakırköy Tıp Dergisi 2014; 10: 158-164.

3. Hacettepe Üniversitesi Nüfus Etütleri Enstitüsü. Türkiye Nüfus Ve Sağlık Arastırması 2003. Available from: URL: http://www.hips.hacettepe.edu.tr/pdf/TNSA2003-AnaRapor.pdf.
4. Brennan R, Gnanaraj L, Cottrell DG. Retinopathy of prematurity in practice. I. Screeningforthresholddisease. Eye 2003; 17: 183-8. [CrossRef]

5. Holmström G, el Azazi M, Jacobson L, Lennerstrand G. A populationbased, prospectivestudy of thedevelopment of ROP in prematurelybornchildren in the Stockholm area of Sweden. Br J Ophthalmol 1993; 77: 417-23. [CrossRef]

6. Schalij-Delfos NE, Zijlmans BL, Wittebol-Post D, Tan KE, Cats BP. Screening for retinopathy of prematurity: do former guidelines still apply? J Pediatr Ophthalmol Strabismus 1993; 33: 35-8.

7. Öner A, Özkırış A, Güneş T, Karaküçük S, Erkılıç K, Çetin N. Prematüre retinopatisi: 2 yıllık tarama sonuçlarımız. Erciyes Tıp Dergisi 2005; 27: 104-9

8. Gilbert C, Foster A. Childhoodblindness in thecontext of VISION 2020-therighttosight. Bull World Health Organ 2001; 79: 227-32.

9. Akkoyun I, Oto S, Yilmaz G, Gurakan B, Tarcan A, Anuk D, et al. Risk factors in the development of mild and severe retinopathy of prematurity. J AAPOS 2006; 10: 449-53. [CrossRef]

10. Seiberth $V$, Linderkamp $O$. Risk factors in retinopathy of prematurity. A multivariatestatisticalanalysis. Ophthalmologica 2000; 214: 131-5. [CrossRef]

11. Aaber T, Ben-Sira I, Charles S. An international classification of retinopathy of prematurity. II. The classification of retinal detachment. The International Committee for the Classification of the Late Stages of Retinopathy of Prematurity. Arch Ophthalmol 1987; 105: 906-12. [CrossRef]

12. TOD ROP Komisyonu, TND ROP Çalışma Grubu. Türkiye Prematürite Retinopatisi Rehberi 2016. Available from: URL: http://www. neonatology.org.tr/wp-content/uploads/2016/12/premature_retinopatisi_rehberi.pdf

13. Palmer EA, Flynn JT, Hardy RJ, Phelps DL, Philips CL, Schafer DB, et al. Incidence and early course of retinopathy of prematurity. The Cryotherapy for Retinopathy of Prematurity Cooperative Group. Ophthalmology 1991; 98: 1628-40. [CrossRef]

14. Gupta VP, Dalival U, Sharma R, Gupta P, Rohatgi J. Retinopathy of prematurity, risk factors. Indian J Pediatr 2004; 71: 887-92. [CrossRef]

15. Smith J, Spurrier N, Goggin M. Retinopathy of prematurity in a South Australianneonatalintensivecareunit. Aust N Z J Ophthalmol 1995; 23: 49-54. [CrossRef]

16. Kavuncuoğlu S, Karaçorlu M, Arıdaşır Ö, Arası C, Yılmaz Ç, Arslan $G$, et al. Riskli prematürelerde retinopati taraması ve sonuçları. Turk Pediatri Ars 2002; 37: 10-4.

17. Sarikabadayi YU, Aydemir O, Ozen ZT, Aydemir C, Tok L, Oguz SS, et al. Screening for retinopathy of prematurity in a large tertiary neonatal intensive care unit in Turkey: frequency and risk factors. Ophthalmic Epidemiol 2011; 18: 269-74. [CrossRef]

18. Kavurt $S$, Yücel H, Hekimoğlu E. Prematüre retinopatisi gelişen olgularda risk faktörlerinin değerlendirilmesi. Çocuk Sağlığı ve Hastalıkları Dergisi 2012; 55: 125-1331.

19. Özcan E, Yenice Ö, Kazokoğlu H, Bavbek T, Toker E, Özek E. Prematüre reinopatisi gelişiminde etkili risk faktörleri ve tarama sonuçları. Ret-Vit 2006;14: 127-32

20. Özbek E, Genel F, Atııhan F, Güngör I, Malatlayı R, Menteş J, Berk T. Yenidoğan yoğun bakım ünitemizde prematüre retinopati insidansı, risk faktörleri ve izlem sonuçları. İzmir Dr. Behçet Uz Çocuk Hastalıkları Dergisi 2011; 1: 7-12.

21. Bas AY, Koc E, Dilmen U, ROP Neonatal Study Group. Incidence and severity of retinopathy of prematurity in Turkey. $\mathrm{Br} \mathrm{J}$ Ophthalmol 2015; 99: 1311-4. [CrossRef]

22. Bülbül A, Okan F, Şahin S, Nuhoğlu A. Düşük doğum ağırlıklı erken doğmuş bebeklerde erken dönem hastalık ve ölüm oranı sonuçları. Turk Pediatri Ars 2008; 43: 94-8

23. Kocabeyoğlu S, Kadayıfcılar S, Eldem B. Prematüre Retinopatisinde Klinik Seyir, Tedavinin Değerlendirilmesi ve Iliş̧kili Risk Faktörlerinin Belirlenmesi. Turk J Opthalmol 2011; 41: 128-32. [CrossRef] 
24. Yalaz M, Arslanoğlu S, Erakgün ET, Yurtsever SN, Akisu M, Akkın C, et al. Prematüre Retinopatisi Risk Faktörleri Ve Koruyucu Önlemler. Turkiye Klinikleri J Pediatr 2003; 12: 1-8.

25. Feeney L, Beman ER. Oxygen toxicity: membrane damage by free radicals. Invest Ophthalmol 1976; 15: 789-92.

26. Martin RJ, Sosenko I, Bancalari E. Respiratoryproblems. In: Martin RJ, Fanaroff AA, Walsh MC, editors. Care of the High Risk Neonate. 5th ed. Philadelphia: WB Saunders; 2001.p.244-5.
27. Chen M, Citil A, McCabe F, Leicht KM, Fiascone J, Dammann CE, et al. Infection, oxygen, andimmaturity: interacting risk factorsforretinopathy of prematurity. Neonatology 2011; 99: 125-32. [CrossRef]

28. Wani VB, Kumar N, Sabti K, Raizada S, Rashwan N, Shukkur MM, Harbi M. Results of screeningforretinopathy of prematurity in a largenursery in Kuwait: Incidenceand risk factors. Indian J Ophthalmol2010; 58: 204-8. [CrossRef] 